\title{
ПРИРОДОКОРИСТУВАННЯ ТА СТІЙКИЙ РОЗВИТОК ТУРИЗМУ В КАРПАТСЬКОМУ РЕГІОНІ УКРАЇНИ
}

\begin{abstract}
Розглянуто основні проблеми природокористування та стійкого розвитку туризму в Карпатському регіоні України, що дало змогу встановити баланс між задоволенням сучасних потреб місцевого населення і захистом інтересів майбутніх поколінь $з$ врахуванням безпечного стану довкілля. Виділено основні пріоритети охорони та екологічно безпечного використання природних ресурсів Українських Карпат в економічній і туристичній діяльності регіону, сформульовано основні принципи стійкого розвитку туризму в регіоні, що дасть змогу органам державної влади вирішити економічні проблеми місцевих громад і підвищить туристичну привабливість регіону. Внаслідок проведеного аналізу наявних планів заходів з реалізації стратегій розвитку областей, прилеглих до Карпатського регіону, на період до 2020 року з'ясовано нагальні проблеми стійкого розвитку туризму в регіоні, діяльність якого має грунтуватися на принципах збалансованого розвитку особи, суспільства й держави в поєднанні з охороною навколишнього середовища, яке їх оточує.

Встановлено, що стійкий розвиток туризму в регіоні Українських Карпат має задовольняти теперішні потреби туристів, відпочивальників і місцевого населення загалом, а також раціонально використовувати наявні природні ресурси й примножувати туристичний потенціал регіону як тепер, так і в майбутньому. З'ясовано, що органам місцевої влади потрібно так здійснювати управління усіма туристичними об'єктами і курортно-рекреаційними комплексами, щоб не тільки задовольняти економічні, соціальні та естетичні потреби туристів і місцевих громад, а й зберігати їхню культурну цілісність, важливі еколого-економічні процеси, біологічну різноманітність і системи життєзабезпечення. Виявлено, що продукція стійкого розвитку туризму, насамперед надані туристичні послуги, має бути узгоджена з місцевим природним середовищем, суспільством $\mathrm{i}$ державою, їхньою культурою і звичаями в такий спосіб, щоб це приносило усім користь, а не збиток туристичній діяльності та гальмувало подальший розвиток туризму.
\end{abstract}

Ключові слова: принципи стійкого розвитку; стратегічне управління; органи державної влади; екологічна безпека довкілля; природні ресурси; економічна діяльність; туристичні об'єкти; курортно-рекреаційні комплекси; культурна спадщина.

Вступ. Сучасний стан екологічної системи і навколишнього середовища Карпатського регіону України заставляє органи місцевої влади змінювати свої погляди на його подальший економічний і технічний прогpec, в т.ч. і туристичний розвиток (Borushchak, 2006; Voroshylova, 2010; Svyda, 2009). Місцева влада змушена оцінювати цей стан 3 урахуванням еколого-економічних пріоритетів (Zhuk, 2012) i наявних ризиків (Grytsiuk, Maksymiv, 2011; Grytsiuk, \& Hrytsiuk, 2017a; Gryciuk, \& Grytsiuk, 2016), а також стану екологічної безпеки (Adamenko, Adamenko, Arkhypova, 2013, 2014; Andrusevych, Andrusevych, \& Kozak, 2009; Kravtsiv, 2013). Для цього органам влади необхідно переглянути наявний стан природокористування (Kravtsiv, et al., 2014; Makarova, Harmider, \& Mykhalchuk, 2007; Safranov, 2009; Tsarenko, \& Zlobin, 1999), проаналізувати та перебудувати туристично-господарську діяльність і курортно-рекреаційний комплекс 3 урахуванням засад стійкого розвитку (Arkhypova, 2013; Arkhypova, 2014b; Holubets, 2007; Zinko, et al., 2009; Trehobchuk, 2002;
Shevchuk, 2006). Ці засади грунтуються на досягненні компромісу між соціально-економічними потребами населення та можливостями навколишнього середовища (Dorohontsov, et al., 2011; Rehionalni dopovidi, 2017; Topornytska, 2012), задоволення яких має відбуватися без загрози нормальному функціонуванню екологічної системи (Hryniv, 2001; Melnyk, 2003; Safranov, 2009).

Загалом, природокористування - це використання властивостей навколишнього природного середовища для задоволення економічних, екологічних, оздоровчих, лікувальних, культурних, естетичних та інших потреб людини. Тому потрібно виробити і впроваджувати в життя таку стратегію і тактику природокористування в Карпатському регіоні (Kravtsiv, et al., 2014; Kravtsiv, 2013; Milashovska, 2008), які б забезпечили інтегральне управління економічною та екологічною системами (Grytsiuk, Grytsiuk, \& Gryciuk, 2017a; Grytsiuk, \& Hrytsiuk, 2017a; Shmandii, \& Soloshych, 2004), організували їх раціональне туристичне навантаження (Blanke, \& Chiesa, 2011; Arkhypova, 2014b; Kravtsiv, et al., 2014; Tkac-

Інформація про автора:

Грицюк Мар'яна Юріївна, аспірант кафедри екологічної економіки, магістр. Email: mariana.grytsiuk@gmail.com

Грицюк Юрій Іванович, д-р техн. наук, професор кафедри програмного забезпечення. Email: yurii.i.hrytsiuk@lpnu.ua; ORCID: http://orcid.org/0000-0001-8183-3466, ResearcherID: V-3995-2017

Цитування за ДСту: Грицюк М. Ю., Грицюк Ю. І. Природокористування та стійкий розвиток туризму в Карпатському регіоні України. Науковий вісник НЛтУ України. 2018, т. 28, № 2. С. 99-110.

Citation APA: Grytsyuk, M. Yu., \& Hrytsiuk, Yu. I. (2018). Nature and Sustainable Development of Tourism in the Carpathian Region Ukraine. Scientific Bulletin of UNFU, 28(2), 99-110. https://doi.org/10.15421/40280219 
henko, 2009), унеможливили надмірне виснаження та забруднення довкілля, а також здійснювали постійний контроль за змінами природних і антропогенних процесів (Diachenko, 2007; Kravtsiv, 2013). Проте, оцінювання проектів стійкого розвитку туризму в Карпатському регіоні, в т.ч. й міжнародних (Press Release, 2018; Andrusevych, Andrusevych, \& Kozak, 2009; Arkhypova, 2013; Voroshylova, 2010; Malska, Antoniuk, \& Hanych, 2008), ще й на сьогодні компетентні органи виконують без достатнього врахування екологічних чинників. Також при виборі варіантів туристичного освоєння регіону органи місцевої влади аналізують й враховують альтернативи недостатньо для того, щоб компенсувати витрати на відтворення навколишнього природного середовища та покращення його екологічного стану.

Аналіз останніх досліджень і публікацій. Початок 90-х років ознаменувався інтенсифікацією наукових досліджень щодо вирішення проблеми збалансованого природокористування та стійкого розвитку суспільства. Свого часу за участю багатьох вчених (Borushchak, 2006; Holubets, 2007; Korobko, 2007; Trehobchuk, 2002; Shevchuk, 2006) була розроблена Концепція сталого розвитку України, яку згодом схвалила Верховна Рада України. Про актуальність даної проблеми свідчить той факт, що ще в 1998 р. при Кабінеті Міністрів України відповідною постановою була створена Національна комісія сталого розвитку України, а до іiі складу увійшли відомі вчені. А Указом Президента України від 12 січня 2015 р., № 5/2015 була схвалена "Стратегія сталого розвитку "Україна - 2020". Наукові основи національної стратегії переходу України на принципи стійкого розвитку грунтуються на властивих державі геополітичних, географічних, демографічних, соціально-економічних і екологічних особливостях.

Проблеми стійкого розвитку Карпатського регіону України та вдосконалення наявної державної політики щодо управління туристичною галуззю не $є$ новими, проте потребують постійних наукових розробок з врахуванням зарубіжного досвіду господарювання (Shupik, 2009; Havrylyshyn, 1994). Це знайшло відображення в дослідженнях таких науковців, як Л. М. Архипової (Arkhypova, 2014a), О. О. Любіцевої (Liubitseva, 2006; Liubitseva, Pankova, \& Stafiichuk, 2007), M. I. Борущак (Borushchak, 2006), О. О. Бейдика (Beidyk, 2001), В. Киф'яка, О. В. Ільїної (Ilina, 2004), А. Олександрової, В. Квартального, І. Колесникової, І. Зоріна, М. Мальської (Malska, Antoniuk, \& Hanych, 2008), Д. I. Басюк (Basiuk, 2005), І. П. Гаврилишина (Havrylyshyn, 1994) та ін. Розвиток інвестиційних процесів у міжнародному туризмі розглянуто у роботі Г. О. Ворошилова (Voroshylova, 2010).

Проблеми регіональної туристичної політики на території Українських Карпат достатньо детально розглянуто в роботах Л. М. Архипової (Arkhypova, 2013; 2014a, 2014b), особливості формування та функціонування ринку надання туристичних послуг детально викладено у працях О. О. Любіцевої (Liubitseva, 2006). Дослідження потенціалу туристично-рекреаційних ресурсів Карпатського регіону висвітлено у численних публікаціях О. О. Бейдика (Beidyk, 2001). Багато авторів досліджують західні туристичні регіони (області) України: М. М. Блага, В. І. Гетьман, В. С. Грицевич, О. П. Дудкіна, В. І. Мацола (Matsola, 1997), М. П. Мальська (Malska, Antoniuk, \& Hanych, 2008), О. А. Марченко, С. П. Кузик й інші. Проте проблеми форму- вання стратегії стійкого розвитку туристичної галузі Карпатського регіону України розкриті недостатньо і потребують подальшого опрацювання, що і визначило актуальність цієї роботи.

Водночас, у багатьох дослідженнях недостатньо вивченими залишаються питання щодо комплексного оцінювання конкурентоспроможності туристичних і курортно-рекреаційних комплексів Карпатського регіону, виявлення та визначення дії різних за природою і суперечливих за характером впливу чинників на допустимий рівень природокористування, на стан екологічної ситуації в регіоні, а також формування дієвих механізмів відновлення довкілля.

Отже, видається доцільним проведення дослідження щодо узгодження проблем природокористування в Карпатському регіоні України з проблемами стійкого розвитку туризму, вирішення яких передбачало б раціональне туристичне навантаження на екологічну систему регіону, а також унеможливило б надмірне виснаження та забруднення, передусім, курортно-рекреаційних об'єктів.

Об'єкт дослідження - природокористування та стійкий розвиток туризму.

Предмет дослідження - методи та засоби забезпечення раціонального природокористування та стійкого розвитку туризму в Карпатському регіоні України

Мета дослідження полягає у виділенні основних пріоритетів охорони та екологічно безпечного використання природних ресурсів Карпатського регіону в туристичній діяльності, формулювання принципів стійкого розвитку туризму, що забезпечать вирішення економічних проблем місцевих громад і підвищать рівень екологічної безпеки довкілля.

Для реалізації зазначеної мети потрібно виконати такі основні завдання:

1) проаналізувати проблеми збалансованої діяльності господарських об'єктів і стійкий розвиток Карпатського регіону, що дасть змогу встановити баланс між задоволенням сучасних потреб місцевого населення і захистом інтересів майбутніх поколінь 3 врахуванням безпечного стану довкілля;

2) з'ясувати проблеми стійкого розвитку туризму в регіоні Українських Карпат, діяльність якого має грунтуватися на принципах збалансованого розвитку особи, суспільства й держави в поєднанні з охороною навколишнього середовища, яке їх оточує;

3) виявити зв'язок між туристичною діяльністю та екологічною безпекою Карпатського регіону, що дасть змогу встановити основні пріоритети охорони та безпечного використання природних об'єктів, а також запропонувати заходи екологічної безпеки на принципах сталого розвитку;

4) зробити відповідні висновки та надати рекомендації щодо ефективного природокористування та стійкого розвитку туризму в Карпатському регіоні України.

\section{1. Збалансована діяльність господарських об'єктів і стійкий розвиток Карпатського регіону}

Поняття збалансованого, тобто стійкого розвитку особи, суспільства й держави є давно відомим і вже досить усталеним. Вперше воно згадувалося ще в роботах Томаса Мальтуса ${ }^{1}$, який зазначав, "... щзо протягом більшої частини існування людства зростання його кількості на кожен встановлений момент часу був обмежений можливостями несної здатності Землі, зумов- 
леної рівнем розвитку життєзабезпечувальних технологій, щзо спостерігалися на певний момент часу".

${ }^{1}$ Томас Роберт Мальтус (англ. Thomas Robert Malthus, 1766-1834рр.) - англійський священик і учений, демограф і економіст, автор теорії, згідно з якою неконтрольоване зростання народонаселення повинне призвести до голоду на Землі.

У своїй праці "Дослід щодо закону народонаселення" (1798 р.) Мальтус вказав на те, що зростання населення без жодних стримулювальних чинників має відбуватися експоненційно $(1 \rightarrow 2 \rightarrow 4 \rightarrow 8)$, водночас як збільшення харчових ресурсів можливе тільки в арифметичній прогресії $(1 \rightarrow 2 \rightarrow 3 \rightarrow 4)$. Наслідком такого розвитку подій Мальтус бачив вимушене повернення кількості населення до рівня, на якому оселя (Земля) здатна підтримувати людську популяцію як результат голоду, хвороб і воєн за обмежені ресурси. Цей сценарій розвитку суспільства отримав назву "мальтузіанської катастрофи" (Dolan, 2000). Для уникнення такого сценарію Мальтус пропагував потребу просування іншого виду стримувальних чинників - превентивних (упереджувальних), таких як регулювання народжуваності, а також заперечував занадто активне втручання держави у процес розгортання описаних вище природних чинників.

Терміни "стійкий розвиток" нерозривно пов'язаний 3 еволюцією людства. Адже не секрет, що у давні часи люди хоча і займалися сільським господарством і промисловим виробництвом (Hryniv, 2001; Korobko, 2007), однак були тісно пов'язані з природою, тобто збалансовано використовували надані їм ресурси. Протягом останнього столітня промисловий розвиток багатьох країн призвів до надмірного виснаження та забруднення довкілля (Dorohontsov, et al., 2011), внаслідок чого змусило наукову спільноту визнати той факт, що економічний розвиток будь-якої країни має певні обмеження, пов'язані, насамперед, з екологічним станом не тільки конкретної території чи регіону, але й планети загалом (Shmandii, \& Soloshych, 2004). Проблема стану навколишнього середовища була розглянута вперше в 1972 році в Стокгольмі на Конференції ООН, яка стала початком діяльності прогресивної спільноти щодо захисту довкілля в планетарному масштабі.

Становлення концепції стійкого розвитку пройшло три основних етапи:

1) В 1992 році в Ріо-де-Жанейро за участю глав 179 держав відбулася перша міжнародна Конференція $\mathrm{OOH} 3$ питань навколишнього середовища та розвитку UNCED (англ. United Nations Conference on Environment and Development). "Порядок денний на XXI століття" головний документ (Agenda 21, 1992), в якому було рекомендовано концепцію стійкого розвитку як основу для подальшого існування світового співтовариства. У тексті підкреслювалось: "... не можна розглядати навколишнє природне середовище й соціально-економічний розвиток як ізольовані області. Висока якість навколишнього природного середовища й здорова економіка для всіх народів світу - дві мети, які мають розглядатися в єдності".

2) 4 вересня 2002 у Йоганнесбурзі (ПАР) відбулася друга Всесвітня Конференція ООН зі стійкого розвитку під назвою "Саміт Землі", що зібрала делегатів з 189 країн. Основними завданнями цієї конференції були оцінка глобальних змін, які відбулися після "Ріо-92", і узгодження "Плану зі стійкого розвитку Землі до 2015 року".
3) 20-22 червня 2012 року в Ріо-де-Жанейро (Бразилія) відбувся третій Міжнародний Форум $\mathrm{OOH} з$ питань стійкого розвитку під назвою "Майбутне, якого ми бажаємо", який отримав назву "Pio-2012" або "Pio+20", де учасники 3188 країн проголосили "... перехід від неспричинення шкоди до створення позитивного соиіального впливу".

На сьогодні відома велика кількість визначень терміну "стійкий розвиток". Кожний автор, залежно від власної сфери знань (техніка й технологія, економіка й екологія та ін.), дає своє визначення або його версію. Наприклад, практично всі науковці України у своїх працях замість терміну "стійкий розвиток" чомусь використовують термін "сталий розвиток", який у практиків асоціюється з застоєм, що спостерігався у 1980-х роках, коли не було жодної динаміки руху. Однак, як зазначає М. Р. Редкліфт, "... невизначеність поняття "стійкий розвиток" є однією з причин підвищеної уваги до нього" (Redclift, 1997).

Найбільш вдале визначення терміну "стійкий розвиток" було сформульовано в доповіді "Наше спільне майбутнє", зробленій в 1987 році Світовою комісією з питань навколишнього середовища та розвитку (WECD): "стійкий розвиток - це розвиток, щзо задовольняє потреби сьогодення та гарантує таку ж можливість майбутнім поколінням". Тоді вважалося (Arkhypova, 2013; Shevchuk, 2006), що таке визначення зосереджує увагу органів державної влади на: концепції вирішення нагальних проблем, особливо потреб бідного населення держави, яким варто надати найвищий пріоритет; концепції обмежених можливостей навколишнього природного середовища у задоволенні теперішніх і майбутніх потреб людства.

Також $з$ цього визначення видно, що коли йдеться про стійкий розвиток певної місцевості, регіону чи держави, то не варто зосереджувати увагу тільки на екологічних питаннях. Стійкий розвиток потрібно сприймати як збалансовану діяльність господарських об'єктів, що гармонійно поєднує використання наявних природних ресурсів, напрями інвестиційної політики (Voroshylova, 2010; Kalchenko, 2009; Kontseptsiia, 2007; Zhuk, 2012), особливості науково-технічного прогресу та інституційні зміни з потребами теперішнього й прийдешніх поколінь. Тому природокористування важлива складова проблеми взаємодії природи та суспільства (Kravtsiv, et al., 2014; Makarova, Harmider, \& Mykhalchuk, 2007; Safranov, 2009; Tsarenko, \& Zlobin, 1999). Характер природокористування змінюється 3 розвитком суспільних формацій і перебуває в тісному взаємозв'язку з рівнем науки та техніки. В умовах науково-технічного прогресу взаємодія між природою та суспільством значно ускладнилася у зв'язку зі зростанням потреб суспільства у природних ресурсах, інтенсивністю і характером впливу людини на природне середовище (Melnyk, 2003). Це призводить до ускладнення екологічної ситуації у окремих регіонах країни, в т.ч. і Карпатському регіоні зокрема (Hryniv, 2001).

Отже, природокористування (англ. Natural Resource Management) - сфера виробничої та наукової діяльності, вся сукупність засобів, які застосовує суспільство задля комплексного вивчення, освоєння, використання, відновлення, поліпшення й охорони навколишнього природного середовища та природних ресурсів для розвитку продуктивних сил, забезпечення сприятливих 
умов життєдіяльності людини (Dorohontsov, et al., 2011). Це сукупність усіх впливів людей на природу, які містять заходи з ії освоєння, перетворення та охорони (Andreitsev, 2010; Orlov, 2001). Природокористування $є$ теорією та практикою раціонального використання людиною природних ресурсів у середовищі суспільновиробничої діяльності, спрямованої на задоволення потреб людства цими ресурсами, а також збереження різноманітності та якості навколишнього середовища (Makarova, Harmider, \& Mykhalchuk, 2007). Тому природокористування і сталий розвиток тісно пов'язані між собою, позаяк спрямовані на організоване й раціональне використання наявних ресурсів, забезпечення охорони навколишнього природного середовища, екологічної безпеки певної території чи регіону тощо.

Три міжнародні організації $\mathrm{IUCN}^{1}, \mathrm{UNEP}^{2}$ та $\mathrm{WWF}^{3}$ у 1991 році запропонували дещо інше визначення стійкого розвитку: "... шллх розвитку, щз справді покращує якість життя людей $i$, водночас, зберігає природне різноманіття планети... Стійкий розвиток означає жити гармонійно з іншими людьми та з природою". У цьому визначенні наголос зроблено на покращенні якості життя людей та важливості їхнього гармонійного співіснування $з$ природою.

${ }^{1}$ Міжнародний союз охорони природи (МСОП; англ. International Union for Conservation of Nature, IUCN) міжнародна організація, метою якої є збереження природних ресурсів.

${ }^{2}$ Програма ООН з навколишнього середовища (ЮНЕП; англ. United Nations Environment Programme, UNEP) - міжурядова програма, створена 3 ініціативи Стокгольмської конференції ООН з навколишнього середовища (1972) i рішення Генеральної Асамблеї ООН (1973р.).

${ }^{3}$ Всесвітній фонд дикої природи (англ. World Wide Fund for Nature) - 31986 року має назву WWF (англ. World Wildlife Fund) - міжнародна неурядова організація, що займається збереженням природи, дослідженнями та відновленням природного середовища. Місія WWF - запобігання наростаючій деградації природного середовища планети і досягненні гармонії людини і природи. Головна мета - збереження біологічної різноманітності Землі. Символ Всесвітнього фонду дикої природи - гігантська панда.

Для вирішення таких комплексних проблем людства потрібно навчитися інтегрально управляти економічною та екологічною системами як єдиним цілим, тобто потрібно збалансувати діяльність господарських об'єктів 3 екологічною безпекою довкілля. Тому в Лансароте (острів у складі Канарських островів) в 1995 р. на Світовій конференції зі стійкого туризму було прийнято відповідну Хартію, в якій зазначено: "стійкий розвиток - ие процес управління глобальними ресурсами, результатом якого має бути їх збереження, щуо, водночас, має привести до збереження природного та культурного багатства". Таке визначення змушує органи державної влади зберігати рекреаційні території та культурно-історичну спадщину, i, водночас, приділяти пильну увагу раціональному використанню природних ресурсів.

У 1987 році Комісія ООН під керівництвом Гру Гарлем Брундтланд ${ }^{4}$ у своїй доповіді сформулювала таке визначення стійкого розвитку: "... розвиток, який задовольняє потреби нинішніх поколінь $i$ не ставить під загрозу можливості наступних поколінь задовольняти свої власні потреби" (Butlin, 1989).

${ }^{4}$ Гру Гарлем Брунтланд (норв. Gro Harlem Brundtland)

- жінка-політик, голова найбільшої партії в Норвегії, пре- м'єр-міністр, відомий міжнародний діяч. Її часто називають найяскравішим політичним діячем сучасної Норвегії.

Отже, стійкий розвиток (англ. Sustainable Development) - загальна концепція стосовно потреби встановлення балансу між задоволенням сучасних потреб людства і захистом інтересів майбутніх поколінь з врахуванням їх потреб в безпечному і здоровому довкіллі (Arkhypova, 2014a; Borushchak, 2006; Holubets, 2007). Це процес економічних і соціальних змін, за яких експлуатація природних ресурсів, напрям інвестицій, орієнтація науково-технічного прогресу, розвиток особистості й інституціональні зміни погоджені один з одним і зміцнюють теперішній і майбутній потенціал для задоволення людських потреб і спрямувань (Shevchuk, 2006).

Термін "стійкий розвиток" є офіційним українським відповідником англійського терміну "Sustainable Development", дослівний переклад якого з урахуванням контексту може бути "життєздатний розвиток" чи "зрівноважений розвиток", а за сенсом - "самопідтримуваний розвиток". Інколи цей термін тлумачать як "всебічно збалансований розвиток" чи просто "збалансований розвиток" особи, суспільства, держави. За визначенням Комісії ООН зі стійкого розвитку, його мета - задовольняти потреби сучасного суспільства, не ставлячи під загрозу здатність майбутніх поколінь задовольняти свої потреби. Теорія стійкого розвитку є альтернативою парадигмі економічного зростання, яка ігнорує екологічну небезпеку від розвитку за екстенсивною моделлю (Коrobko, 2007).

Стійкий розвиток має чотири виміри (Arkhypova, 2013; Shevchuk, 2006), які тісно пов'язані між собою:

- соиіальний - показує взаємозв'язок людей, насамперед рівність та повагу до прав як своїх, так і інших;

- економічний - тісно пов'язаний із системами, що забезпечують виживання людини (навчання, робота, купівля, охорона здоров'я, відпочинок тощо);

- екологічний (природний) - зосереджує увагу на системах, що підтримують життя планети (біосфери, атмосфери, гідросфери, літосфери, космосфери, видового складу флори i фауни та ін.);

- політичний (інституиійний) - вказує на демократичне управління та прийняття рішень з питань раціонального використання природних ресурсів, а також уникнення надмірного забруднення та деградації довкілля.

Стійкий розвиток має деякі характеристики, що відрізняють його від таких форм розвитку, як класична модель і модель необмеженого розвитку, які з'явились протягом останніх десятиліть (Shevchuk, 2006). Класичну модель стійкого розвитку можна розглядати як систему взаємопов'язаних моделей, кожна 3 яких відображає поведінку одного з чотирьох вимірів: соціального, економічного, екологічного і політичного (Borushchak, 2006). Серед моделей необмеженого, так званого експоненціального зростання найбільш відомий закон Мура, який базується на припущенні відсутності будь-яких обмежень розвитку як такого загалом (Trehobchuk, 2002). Водночас, якщо ресурсне забезпечення варіюється довільно або розглядають декілька етапів життєвого циклу, то більш адекватною є S-подібна логістична модель розвитку (Diachenko, 2007).

Отже, головними характеристиками стійкого розвитку Карпатському регіоні (Arkhypova, 2014b; Zinko, et al., 2009) мають бути: 
1) Прямий зв'язок з навколишнім середовищем, тобто діяльність місцевих громад та використання природних ресурсів не можуть перевищувати очисні та відтворювальні можливості екологічної системи. Перевищення цієї здатності призводить до надмірного забруднення та деградації довкілля, що значно зменшує туристичну привабливість регіону.

2) Передбачення майбутніх потреб, тобто люди повинні мати моральний обов'язок зберегти для майбутніх поколінь можливість забезпечити їхні потреби з ресурсів навколишнього середовища, якими володіє сучасне покоління. Адже надмірне вирубування лісів призведе до погіршення як екологічної, так і економічної ситуації в регіоні та, як наслідок, значно зниження його туристичної привабливості.

3) Збереження та покращення якості життя, основу якого становить не тільки матеріальна складова, але й соціальна, моральна та духовна особливості.

4) Рівні можливості, тобто всі адміністративні території та соціальні групи населення регіону мають мати однакові права, рівні можливості та конкретні обов'язки. Першочергова увага повинна приділятися бідним верствам населення та людям з особливими потребами, які мають мати можливість як працювати, навчатися, так і відпочивати чи мандрувати.

5) Принцип обережності, згідно з яким, якщо існує сумнів 3 приводу негативного впливу деякої господарської діяльності чи проектів із розвитку на стан екологічної системи, то вибір варіанту рішення має бути, передусім, на користь захисту довкілля. Наприклад, вибір між промисловим і туристичним об'єктом має грунтуватися не тільки на їх економічній доцільності, але й на потенційно заподіяній шкоді довкіллю.

6) Потреба співвідносити всі проекти чи програми розвитку з впливом на довкілля, згідно з яким вирішення серйозної проблеми навколишнього природного середовища вимагає брати до уваги всі виміри стійкого розвитку: соціального, економічного, екологічного і політичного.

Кожна 3 наведених вище характеристик має здійснювати свій внесок у вирішення різних проблем стійкого розвитку Карпатського регіону і це треба робити доти, доки в місцевого населення, туристів і відпочивальників не появиться так звана "культура" стійкого розвитку, яка забезпечить збалансовану діяльність як господарських об'єктів, так і стійкий розвиток туризму загалом. Адже досягнення стійкості розвитку особи, суспільства й держави - це складний процес, що містить кооперацію на різних рівнях - національному й регіональному, науковому й практичному, а також на рівні 3MI та ін.

\section{2. Проблеми стійкого розвитку туризму в регіоні Українських Карпат}

У 1960-х роках негативний вплив розвитку масового туризму (Tkachenko, 2009) призвів до загальної критики та дискусії щодо розвитку так званого зеленого туризму (Svyda, 2009). Водночас, термін "стійкий туризм" вперше був використаний в 1980-х, коли дослідники й фахівці туристичної галузі працювали над доповіддю Іру Гарлем Брунтланд. Сталося це в Лідсі (Англія) в 1990 році на конференції під назвою "Тіні зеленого кольору", яка пізніше отримала назву "стійкий туризм". Тому 3 початку 1990-х термін "стійкий туризм" почав використовуватись частіше як загальновизнане поняття збалансованої туристичної діяльності. Понад це, i "Конвенція
3 питань біологічного різноманіття", і "План дій 21" (Agenda 21, 1992), прийняті в Ріо-де-Жанейро в 1992 році на Конференції ООН з питань довкілля та розвитку, наголосили на потребі додати туризм як складову до міжнародної політики захисту довкілля.

Концепція стійкого розвитку туризму з'явилась у відповідь на дві проблеми: з одного боку - потреби розвивати прибутковий туризм, а 3 іншого - враховувати обмеження щодо використання наявних природних ресурсів i, що найважливіше, їх збереження для прийдешніх поколінь. Тому в 1996 році Всесвітньою Туристичною Організацією (ВТО) було зроблене таке визначення стійкого туризму: "... процес, який задовольняє потреби сучасних туристів і місиевостей, які їх приймають, $i$, водночас, зберігає та розвиває можливості для майбутнього" (UNWTO, 2010). За цим визначенням стійкий розвиток туризму має задовольняти сьогоденні потреби місцевого населення та їх майбутніх поколінь, а також теперішні й майбутні потреби туристів і сторін, що їх приймають. Окрім цього, стійкий розвиток туризму має слугувати інтересам людей в сфері соціуму, економіки та екології.

Отже, стійкий туризм (англ. Sustainable Tourism) сучасна концепція розвитку туризму, що грунтується на принципах збалансованої туристичної діяльності особи, суспільства й держави в поєднанні з охороною навколишнього середовища, яке їх оточує (Tkachenko, 2009). Це туризм, що має задовольняти всі наявні потреби учасників туристичної діяльності, уникаючи при цьому надмірного навантаження на природні об'єкти й довкілля, але повинен розвиватися так, щоб забезпечити аналогічними можливостями майбутні покоління.

Аналогічне визначення стійкого розвитку туризму можна спостерігати й у "Карпатській конвенції" (Ramkova konventsiia, 2004), створеній 22 травня 2003 року (Київ), яка набула чинності 4 січня 2006 року. Згідно 3 цим визначенням, стійкий туризм - це "... туристична діяльність, за якої управління всіма ресурсами проходить в такий спосіб, щзо ї̈ економічні, соціальні, естетичні потреби повністю задовольняються та зберігається культурна складова, екологічні процеси, біологічне різноманіття та системи підтримки життя". Окрім цього, у "Карпатській Конвенції" виокремлено переваги туризму, які мають отримувати місцеве населення від його розвитку, а саме: "... Сторони вживатимуть заходів для стійкого розвитку туризму в Карпатах, щзо надасть місиевим жителям переваги, виходячи iз особливостей природи, ландмафтів $i$ культурної спадщини, $i$, як наслідок, покращить співробітництво задля досягнення мети".

Попри створення додаткових можливостей для зайнятості місцевої громади, стійкий туризм має допомогти їй зменшити негативний вплив на природне середовище та культурну спадщину, а також сприяти використанню місцевої продукції, в т.ч. й туристичної. Як було написано в Хартії зі стійкого розвитку туризму (1995р.): "... Стійкий туризм трунтується на критеріі стійкості, тобто він має бути екологічно нешкідливим у довготривалій перспективі, економічно дочільним та соичіально рівним для місиевих громад".

В Йоганнесбурзі (ПАР) у 2002 році на Світовому саміті 3 питань стійкого розвитку (Саміт Землі) було зроблено висновок про важливість впровадження принципів стійкості в розвиток туризму, позаяк туризм став 
одним із найбільш енергомістких секторів економіки. Це змусило ВТО в 2004 році переглянути власне визначення цього терміну від 1996 р., внаслідок чого було отримано таке його трактування: "Правила та принципи стійкого розвитку туризму можна застосовувати до усіх форм туризму та типів місиь їхнього розміщення, в т.ч. масовий туризм та інші туристичні продукти. Принцини стійкості стосуються екологічних, економічних і соиіокультурних особливостей розвитку туризму. Потрібно збалансувати ичі три особливості для досягнення довготривалої стійкості".

Різниця між обома визначеннями, зробленими в 1996 і 2004 роках, полягає у виділенні потреби збалансованості трьох вимірів туризму: екологічного, соціального та економічного. Про політичний вимір ще в той час чомусь не йшлося. Понад це, доповнене визначення 2004 р. виокремлює потребу запровадити принципи стійкості в усіх формах туризму, не зважаючи на місце перебування туриста чи вид туристичної діяльності. Згідно 3 цим визначенням, навіть масовий туризм має право існувати та розвиватись за умови виконання ним принципів стійкості (Tkachenko, 2009).

Багато науковців (Beidyk, 2001; Borushchak, 2006; Grytsiuk, Grytsiuk, \& Gryciuk, 2017b; Grytsiuk, \& Hrytsiuk, 2017b; Voroshylova, 2010; Liubitseva, Pankova, \& Stafiichuk, 2007; Malska, Antoniuk, \& Hanych, 2008; Svyda, 2009) протягом останніх декількох десятиліть працювали над створенням основних принципів для ідентифікації концепції стійкого туризму та над способами їх впровадження. Туристичною Радою та Всесвітнім фондом дикої природи (WWF) було запропоновано десять принципів стійкого розвитку туризму, а саме:

1) Стійке використання природних, соціальних і культурних ресурсів, контроль за їхнім збереженням і регулярним відтворенням.

2) Скорочення надмірного споживання та шкідливих викидів - попереджає витрату значних коштів на локалізацію та ліквідацію шкоди, нанесену довкіллю, та підвищує ефективність туристичної діяльності.

3) Збереження природного, сочіального та культурного розмаїття, що є важливим для привабливості регіону та збалансованого розвитку туризму, оскільки створює базу для туристичної діяльності місцевого населення.

4) Урахування туризму в національному та регіональному плануванні, об'єктивне оцінювання наслідків його впливу на екологію довкілля значно підвищує шанси туристичного бізнесу на виживання.

5) Підтримка місиевої економіки, зважання на екологічну ситуацію, відсутність шкоди довкіллю сприяє ефективності туристичного бізнесу та загального успіху учасників туристичної діяльності.

6) Залучення місиевих громад до туристичної діяльності не тільки позитивно впливає на економіку регіону та стан довкілля, а й покращує якість надання туристичних послуг, їхньої автентичності та колориту.

7) Консультування зацікавлених сторін і місцевої громади щодо проблем туристичної діяльності, результати якого сприяють попередженню та вирішенню потенційно можливих конфліктів і їхніх взаємних інтересів.

8) Підготовка місиевого персоналу на всіх етапах туристичної діяльності покращує якість туристичного продукту та кваліфікацію людей, здатних до праці, позаяк набувають певні навики й отримують відповідні знання.

9) Маркетинг туризму надає повну інформацію потенційним клієнтам про туристичну діяльність, підвищує їхню повагу до природного, соціального та культурного середовища місцевості, де їх приймають, та позитивно впливають на рівень їхнього задоволення.

10) Проведення маркетингових досліджень, постійний моніторинг туристичної діяльності та стану довкілля важливі для вирішення наявних проблем і покращення ситуації на місцевості, що опікує клієнтів - відпочивальників, туристів і мандрівників.

Деякі науковці (Adamenko, Adamenko, Arkhypova, 2013; Borushchak, 2006; Hryniv, 2001) термін "стійкий туризм" використовують для того, щоб звернути увагу органів місцевої влади на те, що для досягнення збалансованого розвитку Карпатського регіону потрібно, щоб туризм був інтегрованим в усі сфери економічної діяльності і що деякі виміри туризму не обов'язково мають бути стійкими. Наявність інших понять (рис. 1), що часто використовують замість терміну "стійкий туризм", дещо ускладнює порозуміння як між науковцями, так i усіма іншими учасниками туристичної діяльності.

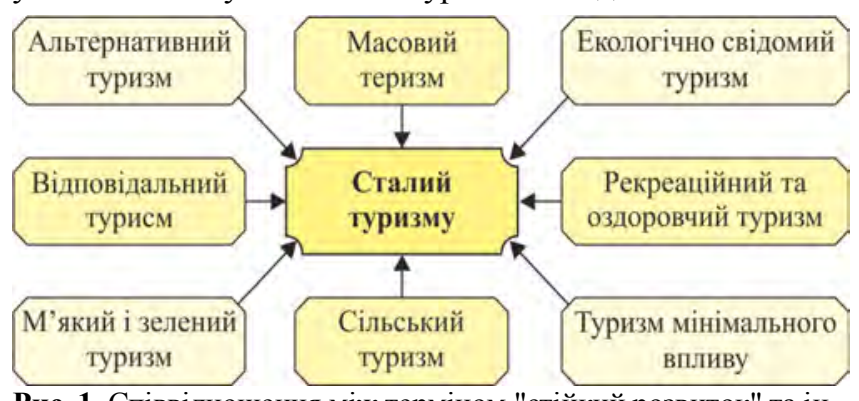

Рис. 1. Співвідношення між терміном "стійкий розвиток" та іншими його поняттями

У багатьох документах (Andrusevych, Andrusevych, \& Kozak, 2009; Matsola, 1997; Smolii, Fedorchenko, \& Tsybukh, 2006; Shupik, 2009) можна знайти співвідношення між терміном "стійкий розвиток" та іншими його поняттями. Однак, відповідальний туризм, м'який туризм, рекреаційний та оздоровчий туризм, природноорієнтований туризм і альтернативний туризм - усі ці терміни мають схожий сенс 3 поняттям стійкого туризму, тому і об'єднані в термін "стійкий туризм". I хоча всі вони в деякий спосіб пов'язані між собою, жодне 3 них не $є$ синонімом. Для зацікавлених сторін туристичної діяльності важливо, щоб існували чіткі межі між цими термінами, тобто різниця між ними має бути однозначно зрозумілою. Наприклад, терміни "м'який туризм", "туризм мінімального впливу", "відповідальний туризм", "екологічно свідомий туризм" означають, що вплив туристичної діяльності на місцеву громаду та довкілля не $\epsilon$ шкідливим (Bocheliuk, \& Bocheliuk, 2006). Отже, тут немає суперечностей, адже всі терміни описують концепцію стійкості туризму, проте кожен з них має свої особливості (Ilina, 2004).

Однак, поняття "альтернативний туризм" та "стійкий туризм" часто використовують як синоніми (Zastavnyi, 2006). Зазвичай, альтернативним називають туризм, що пов'язаний із соціальними, екологічними та культурними цінностями, тобто дає змогу гостям і господарям отримувати позитивні емоції від спілкування та набуття нового досвіду. Часто альтернативний туризм протиставляють масовому та його негативним наслідкам, які були зафіксовані багатьма дослідниками (Babarytska, \& Malynovska, 2004; Khollovei, \& Teilor, 2007). Поряд 3 альтернативним часто використовують відповідальний і м'який туризм, які прийнято вважати 
зеленим туризмом (Bocheliuk, \& Bocheliuk, 2006; Ilina, 2004; Smolii, Fedorchenko, \& Tsybukh, 2006), що перебуває у тісному зв'язку із фізичним і соціальним оточенням, тобто тяжіє до збереження стійкості як такої.

Загалом усі форми туризму можуть бути стійкими (навіть масовий) за умови, що повага до культури та звичаїв місцевого населення, а також природних об'єктів і довкілля будуть їх невід'ємною складовою (Tkachenko, 2009). Проте, деякі види туризму прийнято вважати більш стійкими відносно інших, наприклад: екотуризм, туризм на допомогу бідним, відвідування ярмарків, культових заходів і сільський туризм. Багато науковців вважають (Bocheliuk, \& Bocheliuk, 2006; Doan, 2010; Vovk, 1995; Voronina, 2010; Rutynskyi, \& Topornytska, 2011; Skurativskyi, 1995; Trehobchuk, 2002), що всі види туристичної діяльності, в т.ч. організація свят, фестин і фестивалів, ділові подорожі, конференції, семінари та конгреси, ярмарки і виїзна торгівля, санаторний відпочинок, екстремальний туризм, також мають бути стійкими за умови дотримання відповідних принципів.

Згідно з уточненим визначенням (ВТО, 2004 р.), стійкий туризм має:

1) оптимально використовувати наявні природні об'єкти й пам'ятки старовини, які є ключовими для розвитку туризму, підтримуючи при цьому основні екологічні процеси та допомагаючи органам місцевої влади зберегти історичну спадщину й природне біорозмаїття;

2) поважати соціально-політичну автентичність місцевих громад, що приймають гостей, зберігати їх набуту культурну спадщину і місцеві звичаї та традиції;

3) забезпечити довготривалі економічні процеси і явища, що надають всім зацікавленим сторонам соціальноекономічні переваги, наприклад, стабільне працевлаштування, можливість для заробітку, придбання різноманітної продукції, отримання соціальних послуг, а також подолання бідності.

Отже, стійкий туризм має зосереджувати увагу не тільки на захисті довкілля та повазі до наявної екологічної системи, але й має враховувати економічні, соціальні та культурні особливості кожної місцевості та іiі громади. При цьому активна участь місцевого населення життєво необхідна для впровадження принципів стійкого розвитку туризму незалежно від виду туристичної діяльності. Це спонукає до того, що певні види туризму (екотуризм, сільський туризм) не завжди вважатимуться більш стійкими, ніж інші види туризму, наприклад, масовий.

\section{3. Туристична діяльність та екологічна безпека Карпатського регіону}

Проведений нами комплексний аналіз варіантів стратегічного розвитку туризму в Карпатському регіоні (Gryciuk, \& Grytsiuk, 2016, 2016c; Grytsiuk, Grytsiuk, \& Gryciuk, 2017a; Grytsiuk, \& Gryciuk, 2013a, 2013b; Grytsiuk, \& Hrytsiuk, 2017a) свідчить про те, що органам місцевої влади потрібно здійснювати глибоке екологоекономічне дослідження всіх форм природокористування та наявний стан екологічної безпеки довкілля. Результати такого дослідження даватимуть змогу повністю враховувати шкоду, яку буде завдано довкіллю в процесі туристичної діяльності. При цьому особливу увагу потрібно звернути на планування стратегії розвитку курортно-рекреаційних комплексів регіону, які варто будувати тільки після їх грунтовного аналізу та оптимізації впливу на довкілля (Grytsiuk, Grytsiuk, \& Gryciuk, 2017b; Grytsiuk, \& Gryciuk, 2014; Grytsiuk, \& Hrytsiuk, 2017b; Gryciuk, \& Grytsiuk, 2017).

Загалом екологічна безпека (англ. Ecological Safety) - це такий стан навколишнього природного середовища та умови його перебігу, при якому органи державної влади забезпечують екологічну рівновагу та гарантують захист довкілля: біосфери, атмосфери, гідросфери, літосфери, космосфери, видового складу флори і фауни, природних ресурсів, збереження здоров'я і життєдіяльності людей (Smolii, Fedorchenko, \& Tsybukh, 2006). Часто екологічну безпеку визначають за відношенням до країни, іiі регіонів чи певної території, адміністративних областей і районів, населених пунктів (міст і сіл) або до господарських об'єктів - нафто- і газопроводів, промислових вузлів, заводів, фабрик і інших господарських і туристичних об'єктів, транспорту, енергетики, хімії, гірництва, зв'язку тощо (Tkachenko, 2009).

Багато науковців вважають (Adamenko, Adamenko, Arkhypova, 2014, 2013; Holubets, 2007; Kravtsiv, 2013; Tsarenko, \& Zlobin, 1999), що екологічна безпека Карпатського регіону має грунтуватися на:

- усвідомленні того, що місцеве населення - невід'ємна складова природних і туристичних об'єктів, повністю залежне від стану навколишнього середовища;

- визнанні обмеженості й скінченності природних ресурсів і можливості відновлення довкілля, постійної потреби їх якісної та кількісної інвентаризації;

- неможливості штучного розширення природно-ресурсного (екологічного) потенціалу регіону понад природні та системні обмеження, затверджені в нормативних документах чи встановлені принципами стійкого розвитку;

- визначенні допустимого максимуму використання природних ресурсів і зміни наявної екосистеми як для повноцінного середовища проживання;

- потреби вироблення превентивних екологічних заборон задовго до економічного виснаження природних ресурсів регіону або їх забруднення чи опосередковане руйнування та знищення;

- обов'язковості створення соціально-економічного механізму гомеостазу в системі "людина - природа" типу "природа - товар - гроші - природа" (аналогічно механізму "товар гроші - товар");

- нагальної й обов'язкової потреби регулювання кількості туристів і відпочивальників, їх навантаження на природне середовище на місцевому, регіональному та навіть державному рівнях;

- прийнятності впровадження тільки "екологосумісних" технологій і техніки в усіх сферах господарювання, наприклад, на стадії скидання відпрацьованих рідин у водні об'єкти потрібно дотримуватись вимоги повного вилучення всіх шкідливих компонент, а також повторного використання стічних вод;

- переході до застосування ресурсоощадних технологій і зниження матеріаломісткості промислових виробів, у т.ч. й туристичної продукції, до використання безпечних для природи і місцевого населення прийомів ведення господарської діяльності;

- визнанні закону оптимальності використання, а в господарюванні - принципу розумної достатності при отриманні життєвих благ в просторових і часових конкретних межах, тобто врахування обмежень за вимірами екологічного, соціального і економічного ризику;

- розумінні того, що без адекватного середовища проживання (цілісності екосистеми) неможливо зберегти різні живі організми, в т.ч. людей, флору і фауну, а також природні системи більш низького рівня ієрархії. 
Отже, екологічна безпека Карпатського регіону - це такий стан навколишнього середовища, коли органи місцевої влади мають гарантувати запобігання погіршення стану екологічної ситуації та здоров'я людей (Adamenko, Adamenko, Arkhypova, 2014; Arkhypova, 2013; Zinko, et al., 2009; Rehionalni dopovidi, 2017; Safranov, 2009). Це сукупність їхніх дій, станів і процесів, що прямо або опосередковано не призводять до життєво важливих втрат (або можливості таких втрат), що можна нанести природному середовищу, окремим людям і місцевому населенню загалом. Це такий стан природних і туристичних об'єктів, а також курортнорекреаційних комплексів, який забезпечує екологічний баланс в регіоні чи на будь-якій його території на тому рівні, до якого фізично, соціально-економічно, технологічно й політично готове (може адаптуватися без серйозних втрат) місцеве населення, насамперед, під час отримання матеріальних і суспільних вигод.

Пріоритетом для стійкого розвитку туризму в Карпатському регіоні можна вважати задоволення найважливіших для проживання потреб і прагнень місцевого населення шляхом реалізації функцій туризму як специфічного виду діяльності. При цьому управління всіма видами ресурсів потрібно здійснювати так, щоб соціальні, естетичні та економічні потреби місцевого населення були задоволені в інтеграції з підтримкою їх культурних і екологічних цінностей, враховуючи згубний вплив на місцеве біологічне розмаїття та системи його життєзабезпечення.

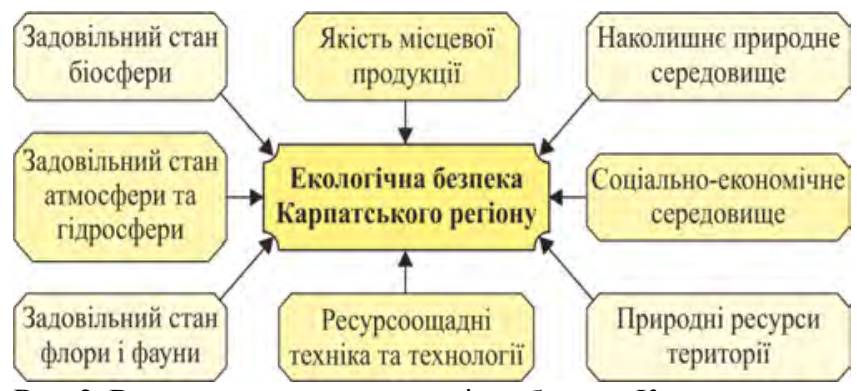

Рис. 2. Вплив складових на екологічну безпеку Карпатського регіону

Основні пріоритети охорони та безпечного використання природних об'єктів Карпатського регіону в туристичній діяльності, а також реалізація заходів екологічної безпеки мають грунтуватись на таких основних принципах (damenko, Adamenko, Arkhypova, 2013, 2014; Arkhypova, 2014a, 2014b; Rehionalni dopovidi, 2017):

1. Забезпечення можливості досягнення раціонального природокористування та збереження природної екосистеми, що вимагає від органів місцевої влади заміни галузевого підходу до планування використання природних ресурсів системним підходом, запроваджуючи при цьому інтегральне управління екосистемою, забезпечуючи дотримання екологічно обгрунтованих норм їх використання. Необхідно також скоротити обсяги скидання забруднених стічних вод, об'ємів викидів шкідливих речовин у атмосферу за рахунок удосконалення технологічних процесів у готельно-ресторанній, санаторно-курортній та інших сферах, на яких грунтується туристична діяльність регіону.

2. Недопущення необгрунтованого та незаконного використання природних об'єктів не за призначенням, порушення чинного законодавства щодо природокористування при обгрунтуванні моделей туристично-рекре- аційного розвитку територій, особливо під час прокладання транспортних шляхів.

3. Пріоритет екологічної безпеки довкілля регіону над потребою використання його природних ресурсів для забезпечення життєдіяльності місцевого населення чи розбудови господарських і туристичних об'єктів. Дотримання в усіх сферах економічної діяльності природоохоронних вимог і основних принципів стійкого розвитку: системності, безперервності, не виснажливості, відтворення, збереження, запобігання та охорони.

4. Нормування та обмеження антропогенного навантаження на природні об'єкти вимагає від органів місцевої влади зміни наявної структури туристичного сектора економіки, хаотично створеного в минулому. Наприклад, у мережі сільського туризму Карпатського регіону помітна недостатня потужність і ефективність споруд для очищення комунально-побутових стічних вод, або вони взагалі відсутні. При цьому внаслідок тривалої експлуатації (понад 60-90 років) значна частина водопровідних мереж вимагають нагальної зміни, як і аналогічне енергомістке обладнання - давно амортизоване й морально застаріле.

5. Захист природних і туристичних об'єктів від шкідливого впливу природних і антропогенних чинників, забруднення побутово-промисловими відходами, хімічними, біологічними та радіоактивними ксенобіотиками. Охорона курортно-рекреаційних комплексів як цінного туристичних ресурсу має забезпечити їх тривалу конкурентоспроможність, а також стати невід'ємною складовою економіки регіону.

6. Відшкодування збитків, заподіяних через порушення природоохоронного законодавства України, що призводить до погіршення екологічного стану довкілля навіть в умовах значного спаду промислового виробництва. Наприклад, внаслідок щорічної динаміки туристичного потоку в Карпатському регіоні існує позитивна тенденція щодо забруднення навколишнього середовища твердими побутовими відходами і стічними водами.

7. Поєднання заходів економічного стимулювання та юридичної відповідальності в галузі охорони природних і туристичних об'єктів, а також культурно-історичної спадщини унеможливлює їхнє навмисне руйнування як місцевим населенням, так і туристами й відпочивальниками, а також сприяє належному збереженню, постійному догляду за їхнім станом і регулярному відновленню.

8. Постійне удосконалення системи моніторингу та контролю за станом екологічної безпеки Карпатського регіону вимагає від органів місцевої влади достатнього фінансування, позаяк технічно-застарілі засоби вимірювальної техніки та їхня мала кількість у відповідних лабораторіях не сприяють належному виконанню зазначених дій. Понад це, сьогодні на державному рівні відбувається скорочення мережі проектів й програм щодо спостережень за станом довкілля та його екологічного моніторингу, а відсутність автоматизованої системи збору інформації про стан природних і туристичних об'єктів призводить до прийняття невчасних й не зовсім обгрунтованих управлінських рішень.

9. Стійка тенденція щодо необгрунтованого збільшення обсягів споживання природних ресурсів вимагає від органів місцевої влади розроблення відповідних технологічних норм їх використання на туристичних об'єктах, запровадження заходів енергозбереження та енергоефективних технологій життєзабезпечення на цих об'єктах. 
10. Впровадження постійних природоохоронних заходів у Карпатському регіоні, недопущення забудови вільних територій туристичними об'єктами без врахування ймовірності їх затоплення, наявності зсувонебезпечних ділянок, селевих потоків, карсту тощо. Наприклад, при влаштуванні туристичних об'єктів потрібно домогтися унеможливлення значного (> 20\%) зменшення лісистості території, зниження верхньої межі гірської лісистості, порушення вікової структури і спрощення видового складу лісових насаджень. Внаслідок туристичного освоєння гірських територій потрібно уникати руйнування біогеоценотичного покриву і функціональну цілісність природної екосистеми, а також запобігати порушенню оптимальної структури ландшафтних компонент, що їх формують.

11. Впровадження постійних водоохоронних заходів у прибережних смугах водних об'єктів і природоохоронних зонах, а саме: закріплення їх меж відповідними бар'єрами, створення захисних лісонасаджень та травостою, здійснення постійного контролю за дотриманням режиму їх використання, регламентованого чинним законодавством. Виділення цього пріоритету пов'язано з тим, що більше, ніж 75 \% всієї туристичної діяльності розгортається в межах прибережних територій водних об'єктів регіону Українських Карпат.

12. Впровадження системи управління навколишнім природним середовищем згідно з вимогами стандарту ISO14000 (ДСТУ-14000-97).

Отже, в сучасних умовах господарської діяльності під час проектування, будівництва й експлуатації туристично-рекреаційних комплексів екологічну безпеку Карпатського регіону потрібно забезпечувати шляхом застосування найбільш раціональних ресурсоощадних технологій та енергомісткого обладнання. На стадії використання та споживання природних ресурсів пріоритет потрібно віддавати запобіганню зміні їх якості, передбаченню можливості втрат цінних природних об'єктів, застосуванню новітніх, більш досконалих систем очищення стічних вод та перероблення твердих побутових відходів, запровадження заходів щодо відновлення порушеної рівноваги у навколишньому середовищі.

Загалом, екологічна безпека території Українських Карпат буде відповідати вимогам стійкого розвитку туризму за умови збереження позитивного кількісного й якісного потенціалу туристичного бізнесу, при врахуванні гранично допустимого навантаження на природні об'єкти та екосистему, при дотриманні вимоги збалансованого планування й проектування 3 врахуванням можливих ризиків, а також ефективної експлуатації наявних туристичних об'єктів і курортно-рекреаційних комплексів.

\section{Висновки}

Виділено основні пріоритети охорони та екологічно безпечного використання природних ресурсів Українських Карпат в економічній і туристичній діяльності регіону, сформульовано основні принципи стійкого розвитку туризму в регіоні, що дасть змогу вирішити економічні проблеми місцевих громад і підвищить рівень екологічної безпеки довкілля. За результатами виконання дослідження можна зробити такі основні висновки:

1) проаналізовано основні проблеми збалансованої діяльності господарських об'єктів і стійкий розвиток Карпатського регіону, що дало змогу встановити баланс між задоволенням сучасних потреб місцевого населен- ня і захистом інтересів майбутніх поколінь з врахуванням безпечного стану довкілля;

2) з'ясовано нагальні проблеми стійкого розвитку туризму в регіоні Українських Карпат, діяльність якого має грунтуватися на принципах збалансованого розвитку особи, суспільства й держави в поєднанні з охороною навколишнього середовища, яке їх оточує;

3) виявлено зв'язок між туристичною діяльністю та екологічною безпекою Карпатського регіону, що дало змогу встановити основні пріоритети охорони та безпечного використання природних об'єктів, а також запропоновано заходи екологічної безпеки регіону на принципах сталого розвитку.

Встановлено, що стійкий розвиток туризму в регіоні Українських Карпат має задовольняти теперішні потреби туристів, відпочивальників і місцевого населення загалом, а також раціонально використовувати наявні природні ресурси й примножувати туристичний потенціал регіону як тепер, так і в майбутньому.

3'ясовано, що органам місцевої влади потрібно так здійснювати управління усіма туристичними об'єктами і курортно-рекреаційними комплексами, щоб задовольняти економічні, соціальні та естетичні потреби туристів і місцевих громад, а також зберігати їхню культурну цілісність, важливі еколого-економічні процеси, біологічну різноманітність і системи життєзабезпечення.

Виявлено, що надані туристичні послуги мають бути узгоджені насамперед 3 можливостями місцевого природного середовища, 3 економічними потребами i можливостями суспільства і держави, їхньою культурою і звичаями. Це потрібно робити в такий спосіб, щоб туристична діяльність приносила усім користь, а не збиток туристичному бізнесу.

\section{Перелік використаних джерел}

Adamenko, O. M., Adamenko, Ya. O. (Eds.), Arkhypova, L. M., et al. (2014). Ekolohichna bezpeka terytorii: kolektyvna monohrafiia; IFNTUNH. Ivano-Frankivsk: Suprun V. P. 444 p. [in Ukrainian].

Adamenko, O. M., Adamenko, Ya. O. (Eds.), Arkhypova, L. M., et al. (2013). Ekolohichna bezpeka zbalansovanoho resursokorystuvannia $v$ Karpatskomu rehioni: naukova monohrafiia. Ivano-Frankivsk: Symfoniia forte. 368 p. [in Ukrainian].

Agenda 21. (1992). United Nations Conference on Environment \& Development. Rio de Janerio, Brazil, 3 to 14 June 1992. 351 p. Retrieved from: https://sustainabledevelopment.un.org/content/documents/Agenda21.pdf

Andreitsev, V. I. (Ed.) (2010). Ekolohichne pravo. Osoblyva chastyna: pidruchnyk dlia stud. yuryd. VUZiv i fakultetiv. Kyiv: Istyna. 260 p. [in Ukrainian].

Andrusevych, A., Andrusevych, N., \& Kozak, Z. (2009). Dovidnyk chynnykh mizhnarodnykh dohovoriv Ukrainy u sferi okhorony dovkillia. Lviv: Resursno-analitychnyi tsentr "Suspilstvo i dovkillia". 203 p. [in Ukrainian].

Arkhypova, L. M. (2013). Stalyi rozvytok terytorii - osnova mizhnarodnoho turyzmu v Ukrainskykh Karpatakh. Ekonomika. Upravlinnia. Innovatsii. Seriia: Ekonomichni nauky, 2(10). 16 p. Retrieved from: http://nbuv.gov.ua/UJRN/eui_2013_2 4. [in Ukrainian].

Arkhypova, L. M. (2014a). Hranychna mistkist ta stalyi rozvytok rekreatsiinoi zony "Bukovel". Ekolohichna bezpeka ta zbalansovane resursokorystuvannia: naukovo-tekhnichnyi zhurnal, 2(10), 93100. Ivano-Frankivsk: Symfoniia forte. [in Ukrainian].

Arkhypova, L. M. (2014b). Stratehiia staloho rozvytku turyzmu Karpatskoho rehionu. Ekonomika. Upravlinnia. Innovatsii. Seriia: Ekonomichni nauky, 2(12). 8 p. Retrieved from: http://nbuv.gov.ua/UJRN/eui_2014_2 4. [in Ukrainian].

Babarytska, V. K., \& Malynovska, O. Yu. (2004). Menedzhment turyzmu. Turopereitynh. Poniatiino-terminolohichni osnovy, servis- 
ne zabezpechennia turproduktu: navch. posibn. Kyiv: Alterpres. 288 p. [in Ukrainian].

Basiuk, D. I. (2005). Osnovy turyzmolohii: navch. posibn. KamianetsPodilskyi: Aksioma. 202 p. [in Ukrainian].

Beidyk, O. O. (2001). Rekreatsiino-turystski resursy Ukrainy: metodolohiia ta metodyka analizu, terminolohiia, raionuvannia: monohrafiia. Kyiv: VPTs "Kyiv. un-t". 295 p. [in Ukrainian].

Blanke, J. \& Chiesa, Th. (Eds.) (2011). The Travel \& Tourism Competitiveness Report 2011. Beyond the Downturn. World Economic Forum. Geneva, Switzerland. 531 p.

Bocheliuk, V. Yo., \& Bocheliuk, V. V. (2006). Dozvillieznavstvo: navch. posibn. Kyiv: TsUL. 208 p. [in Ukrainian].

Borushchak, M. (2006). Problemy formuvannia stratehii rozvytku turystychnykh rehioniv: monohrafiia. Lviv: IRD NAN Ukrainy. 288 p. [in Ukrainian].

Butlin, John. (1989). Our common future. By World commission on environment and development. (London, Oxford University Press, 1987, pp. 383, £5.95). Journal of International Development (en), 1(2). 284-287. https://doi.org/10.1002/jid.3380010208

Diachenko, L. P. (2007). Ekonomika turystychnoi haluzi. Kyiv: Tsentr navch. lit-ry. 224 p. [in Ukrainian].

Doan, P. V. (2010). Svitovi perspektyvy festyvalnoho turyzmu Ukrainy. Heohrafiia ta turyzm: naukova zbirka, 3, 31-37. Kyiv: Alterpres. [in Ukrainian].

Dolan, Brian (2000). Malthus, Medicine, \& Morality: 'Malthusianism' After 1798. Rodopi. $232 \mathrm{p}$.

Dorohontsov, S. I., Khvesyk, M. A., Horbach, L. M., \& Pastushenko, P. P. (2011). Pryrodne seredovyshche u suchasnomu vymiri. Pryrodokorystuvannia v Ukraini, 4, 142-148. Kyiv. [in Ukrainian].

Gryciuk, Yu. I., \& Grytsiuk, M. Yu. (2016c). Modeling of the strategies of behavior of competitive firms in the market of providing tourist services. Bulletin of the National University "Lviv Polytechnic". Series: Information systems and networks, 854, 50 62. Lviv: Vyd-vo NU "Lvivska politekhnika". [in Ukrainian].

Gryciuk, Yu. I., \& Grytsiuk, M. Yu. (2017). Formalization of the strategic planning process for the development of regional tourism in Ukraine. Bulletin of the National University "Lviv Polytechnic". Series: Computer Science and Information Technology, 864, 24-36. Lviv: Vyd-vo NU "Lvivska politekhnika". [in Ukrainian].

Gryciuk, Yurij, \& Grytsiuk, Mariana. (2016). Models strategies of behavior competitive agencies on the market of providing tourist services. Computer Science and Information Technologies: Proceedings of $X^{\text {th }}$ International Scientific and Technical Conference (CSIT2016), (pp. 67-69), 06-10 September, Lviv, Ukraine. Lviv: Lviv Polytechnic National University.

Grytsiuk, M. Yu., \& Gryciuk, Yu. I. (2013a). Mathematical support of decision support system for choosing the tourism development trajectory in the Ukrainian Carpathians region. Intellectual systems of making decision and problem of calculable intellect (ISDMCI2013): mater. Mizhnar. nauk. konf., zb. nauk. prats, (s. 352-355), 20-24 travnia 2013 r., m. Yevpatoriia. Kherson: Vyd-vo KhNTU. [in Ukrainian].

Grytsiuk, M. Yu., \& Maksymiv, L. I. (2011). Metodyka vyznachennia kompleksnoho pokaznyka ryzyku stanu hospodarskoi diyalnosti turystychnoho obiekta. Scientific Bulletin of UNFU, 21(1), 300307. Lviv: RVV NLTU Ukrainy. [in Ukrainian].

Grytsiuk, M. Yu., \& Gryciuk, Yu. I. (2013b). Methods of complex evaluation of options for strategic tourism development. Bulletin of the National University "Lviv Polytechnic". Series: Computer Science and Information Technology, 672, 110-119. Lviv: Vyd-vo NU "Lvivska politekhnika". [in Ukrainian].

Grytsiuk, M. Yu., \& Gryciuk, Yu. I. (2014). Optimization of the strategic tourism development project in the Ukrainian Carpathians region. Bulletin of the National University "Lviv Polytechnic". Series: Computer Science and Information Technology, 826, 13-21. Lviv: Vyd-vo NU "Lvivska politekhnika". [in Ukrainian].

Grytsiuk, M. Yu., \& Hrytsiuk, Yu. I. (2017a). The risks analysis in projects management of sustainable tourism development in the carpathian region of ukraine. Scientific Bulletin of UNFU, 27(5), 164-174. https://doi.org/10.15421/40270532. [in Ukrainian].
Grytsiuk, M. Yu., \& Hrytsiuk, Yu. I. (2017b). Building a sustainable tourism development strategy in the Carpathian region of Ukraine. Scientific Bulletin of UNFU. Economical series, 27(2), 130-136. Lviv: RVV NLTU Ukrainy. https://doi.org/10.15421/40270228. [in Ukrainian].

Grytsiuk, M. Yu., Grytsiuk, P. Yu., \& Gryciuk, Yu. I. (2017a). The risks analysis in projects management of sustainable tourism development in the Carpathian region of Ukraine. In L. Karczewski, H. A. Kretek (red.). Kulturowe, spoleczne, prawne i etyczne aspekty zarzadzania gospodarka i biznesem. Chapter: Multidisciplinary determinants of business and management, (pp. 215-229). Raciborz: Wydawnictwo Panstwowej Wyzszej Szkoly Zawodowej w Reciborzu. $318 \mathrm{p}$.

Grytsiuk, M., Grytsiuk, P., \& Gryciuk, Yu. (2017b). Building a sustainable tourism development strategy in the Carpathian region of Ukraine. Zeszyty Naukowe Politechniki Ślaskiej. Seria Organizacja $i$ Zarzadzanie [Scientific Papers of Silesian University of Technology. Organization and Management Series], czwartek, 21 września 2017, (Zeszyt 104, pp. 35-50). Gliwice, Poland: Politechnika Śląska. https://doi.org/10.29119/1641-3466.2017.104.3

Havrylyshyn, I. P. (1994). Turyzm Ukrainy: problemy i perspektyvy: monohrafiia. Kyiv. 178 p. [in Ukrainian].

Holubets, M. A. (Ed.). (2007). Kontseptualni zasady staloho rozvytku hirskoho rehionu: monohrafiia. Lviv: Polli. 288 p. [in Ukrainian].

Hryniv, L. S. (2001). Ekolohichno zbalansovana ekonomika: problemy teorii: monohrafiia. Lviv: LNU im. Ivana Franka. 240 p. [in Ukrainian].

Ilina, O. V. (2004). Turyzm. Rekreatsiina heohrafiia. Poniattia i terminy: dovidnyk. Lutsk: Teren. 104 p. [in Ukrainian].

Kalchenko, O. M. (2009). Problemy formuvannia investytsiinoi polityky v turystychnii haluzi. Visnyk Chernihivskoho derzhavnoho tekhnolohichnoho universytetu. Seriia: Ekonomichni nauky, (pp. 23-31). Chernihiv: ChNTU. 238 p. [in Ukrainian].

Khollovei, Dzh. K., \& Teilor, N. (2007). Turisticheskii biznes. (7en ed. Trans. from English). Kiev: Znannia. 798 p. [in Russian].

Kontseptsiia. (2007). Kontseptsiia natsionalnoi ekolohichnoi polityky Ukrainy na period do 2020 roku, skhvalena rozporiadzhenniam Kabinetu Ministriv Ukrainy vid 17 zhovtnia 2007 r., № 880-r. Ofitsiinyi visnyk Ukrainy, 79. St. 2961. [in Ukrainian].

Korobko, B. (2007). Enerhetyka ta stalyi rozvytok. Informatsiinyi posibnyk dlia ukrainskykh ZMI. Kyiv: Vyd-vo VEHO "Mama-86". 44 p. [in Ukrainian].

Kravtsiv, V. S. (Ed.) (2013). Karpatskyi rehion: aktualni problemy ta perspektyvy rozvytku: monohrafiia (In 8 vol.). Vol. 1. Ekolohichna bezpeka ta pryrodno-resursnyi potentsial. Lviv: IRD NAN Ukrainy. 336 p. [in Ukrainian].

Kravtsiv, V. S. (Ed.), Zhuk, P. V., Hulych, O. I., et al. (2014). Stale pryrodokorystuvannia u Karpatskomu rehioni Ukrainy: otsinka, problemy, perspektyvy (naukova dopovid). Lviv: IRD NAN Ukrainy. 120 p. [in Ukrainian].

Liubitseva, O. O. (2006). Rynok nadannia turystychnykh posluh. Kyiv: Alterpres. 436 p. [in Ukrainian].

Liubitseva, O. O., Pankova, Ye. V., \& Stafiichuk, V. I. (2007). Turystychni resursy Ukrainy. Kyiv: Alterpres. 369 p. [in Ukrainian].

Makarova, N. S., Harmider, L. D., \& Mykhalchuk, L. V. (2007). Ekonomika pryrodokorystuvannia: navch. posibn. Kyiv: Tsentr navch. lit-ry. 322 p. [in Ukrainian].

Malska, M. P., Antoniuk, N. V., \& Hanych, M. M. (2008). Mizhnarodnyi turyzm i sfera posluh. Kyiv: Znannia. 661 p. [in Ukrainian].

Matsola, V. I. (1997). Rekreatsiino-turystychnyi kompleks Ukrainy: monohrafiia. Lviv: IRD NAN Ukrainy. 259 p. [in Ukrainian].

Melnyk, L. H. (2003). Ekolohichna ekonomika: pidruchnyk. Sumy: VTD "Universytetska knyha". 348 p. [in Ukrainian].

Milashovska, O. (2008). Rehionalna polityka sotsialno-ekonomichnoho rozvytku prykordonnykh rehioniv: monohrafiia. Uzhhorod: Karpaty. 512 p. [in Ukrainian].

Orlov, M. (2001). Pravove zabezpechennia realizatsii ekolohichnykh interesiv - osnova nalezhnoi okhorony dovkillia i rozvytku ekonomiky Ukrainy. Pravo Ukrainy, 1, 68-71 p. [in Ukrainian].

Press Release. (2018, January). 2017 International Tourism Results: the highest in seven years. Specialized agency of the United Nati- 
ons. World Tourism Organization UNWTO. Retrieved from: $\mathrm{http} / / /$ media.unwto.org/press-release/2018-01-15/2017-international-tourism-results-highest-seven-years

Ramkova konventsiia. (2004). Ramkova konventsiia pro okhoronu ta stalyi rozvytok Karpat (Karpatska konventsiia). Vidomosti Verkhovnoi Rady, 32. St. 383. [in Ukrainian].

Redclift, M. R. (1997). Environmentalism: Sustainable development; Environmental policy; Social ecology; Human ecology; Social aspects. Edward Elgar. 485 p.

Rehionalni dopovidi (2017). Rehionalni dopovidi pro stan navkolyshnoho seredovyshcha u oblastiakh Ukrainy stanom na 1 zhovtnia 2017. Ministerstvo ekolohii ta pryrodnykh resursiv Ukrainy. Retrieved from: https://menr.gov.ua/news/31778.html. [in Ukrainian].

Rutynskyi, M. Yo., \& Topornytska, M. Ya. (2011). Etnofestyvalnyi turyzm: teoretychni zasady y etnoheohrafichni aspekty orhanizatsii Heohrafiia ta turyzm: nauk. zb., (pp. 82-93). Kyiv: Alterpres. [in Ukrainian].

Safranov, T. A. (2009). Ekolohichni osnovy pryrodokorystuvannia: navch. posibn. dlia stud. VNZ. Lviv: Vyd-vo "Novyi Svit-2000". 248 p. [in Ukrainian].

Shevchuk, V. ya. (2006). Makroekonomichni problemy staloho rozvytku. Kyiv: Heo-prynt. 200 p. [in Ukrainian].

Shmandii, V. M., \& Soloshych, I. O. (2004). Upravlinnia pryrodookhoronnoiu diyalnistiu: navch. posibn. Kyiv: Tsentr navch. lit-ry. 296 p. [in Ukrainian].

Shupik, B. V. (2009). Zarubizhnyi dosvid u rehuliuvanni turyzmu. Derzhava ta rehiony, 1, 200-207. [in Ukrainian].

Skurativskyi, V. T. (1995). Didukh: sviata ukrainskoho narodu. Kyiv: Osvita. 272 p. [in Ukrainian].

Smolii, V. A., Fedorchenko, V. K. (Ed.), \& Tsybukh, V. I. (2006). Entsyklopedychnyi slovnyk-dovidnyk z turyzmu. Kyiv: Vyd. dim "Slovo". 372 p. [in Ukrainian].

Svyda, I. V. (2009). Suchasnyi stan, aktualni problemy ta perspektyvy rozvytku vitchyznianoho rynku nadannia turystychnykh posluh.
Naukovyi visnyk Uzhhorodskoho universytetu, 28(3), 64-69. [in Ukrainian].

Tkachenko, T. I. (2009). Stalyi rozvytok turyzmu: teoriia, metodolohiia, realii biznesu: monohrafiia. (2nd ed.). Kyiv: Vyd-vo KNTEU. 463 p. [in Ukrainian].

Topornytska, M. Ya. (2012). Etnofestyvalnyi turyzm yak perspektyvna forma sotsialno-ekonomichnoho rozvytku rehioniv Ukrainy. Sotsialno-ekonomichni problemy Ukrainy v hlobalnomu prostori: mater Mizhnar. nauk.-prakt. konf., (pp. 385-388), 26-27 kvitnia 2012, m. Chernivtsi. Chernivtsi. [in Ukrainian].

Trehobchuk, V. (2002). Kontseptsiia staloho rozvytku dlia Ukrainy. Visnyk NAN Ukrainy, 2, 31-40. [in Ukrainian].

Tsarenko, O. M., \& Zlobin, yu. A. (1999). Navkolyshnie seredovyshche ta ekonomika pryrodokorystuvannia: navch. posibn. Kyiv: Vyshcha shk. 176 p. [in Ukrainian].

UNWTO. (2010). World Tourism Organization. Tourism Market Trends UNWTO, 9(1), January 2010. Retrieved from: http://www.UNWTO.org/facts/eng/barometer.htm

Voronina, H. B. (2010). Festyvalnyi turyzm yak novyi napriam svitovoho turyzmu. Heohrafiia ta turyzm: nauk. zb., 10, 31-34. Kyiv: Alterpres. [in Ukrainian].

Voroshylova, H. O. (2010). Rozvytok investytsiinykh protsesiv u mizhnarodnomu turyzmi. Problemy rozvytku zovnishnoekonomichnykh zviazkiv i zaluchennia inozemnykh investytsii: rehionalnyi aspekt. Donetsk: Donetsk. NU. 1050 p. [in Ukrainian].

Vovk, Kh. (1995). Studii z ukrainskoi etnohrafii ta antropolohii. Kyiv: Lybid. 330 p. [in Ukrainian].

Zastavnyi, F. D. (2006). Problemy depresyvnosti v Ukraini (sotsialnoekonomichnoi, ekolohichnoi, demohrafichnoi): monohrafiia. Lviv: VTs LNU im. I. Franka. 348 p. [in Ukrainian].

Zhuk, P. V. (2012). Terytorii priorytetnoho rozvytku yak forma aktyvizatsii investytsiinoi diialnosti $\mathrm{v}$ hirskykh zonakh Ukrainy. Rehionalna ekonomika, 3, 75-85. [in Ukrainian].

Zinko, Yu. V., Rutynskyi, M. Y., Kudla, N. Ye., et al. (2009). Zberezhennia ta stalyi rozvytok Karpat: navch. posibn. Kyiv. 60 p. [in Ukrainian].

М. Ю. Грицюк', Ю. И. Грыцюк ${ }^{2}$

${ }^{1}$ Начиональный лесотехнический университет Украины, г. Львов, Украина

${ }^{2}$ Национальный университет "Львовская политехника", г. Львов, Украина

\section{ПРИРОДОПОЛЬЗОВАНИЕ И УСТОЙЧИВОЕ РАЗВИТИЕ ТУРИЗМА} В КАРПАТСКОМ РЕГИОНЕ УКРАИНЫ

Рассмотрены основные проблемы природопользования и устойчивого развития туризма в Карпатском регионе Украины, что дало возможность установить баланс между удовлетворением современных потребностей местного населения и защитой интересов будущих поколений с учетом безопасного состояния окружающей среды. Выделены основные приоритеты охраны и экологически безопасного использования природных ресурсов Украинских Карпат в экономической и туристической деятельности региона, сформулированы основные принципы устойчивого развития туризма в регионе, которые дадут возможность органам государственной власти решить экономические проблемы местных общин и повысит туристическую привлекательность региона. В результате проведенного анализа имеющихся планов мероприятий по реализации стратегии развития областей, принадлежащих к Карпатскому региону, на период до 2020 года выяснены неотложные проблемы устойчивого развития туризма в регионе, деятельность которого должна основываться на принципах сбалансированного развития личности, общества и государства в сочетании с охраной окружающей среды. Выявлена связь между туристической деятельностью и экологической безопасностью Карпатского региона, что дало возможность установить основные приоритеты охраны и безопасного использования естественных объектов, а также предложены меры экологической безопасности региона на принципах устойчивого развития.

Установлено, что устойчивое развитие туризма в регионе Украинских Карпат должно удовлетворять нынешние потребности как туристов и отдыхающих, так и местного населения в целом, а также рационально использовать имеющиеся природные ресурсы и приумножать имеющийся туристический потенциал региона. Выяснено, что органам местной власти нужно так осуществлять управление всеми туристическими объектами и курортно-рекреационными комплексами, чтобы не только удовлетворять экономические, социальные и эстетические потребности туристов и местных общин, но и охранять их культурную целостность, важные эколого-экономические процессы, биологическое разнообразие и системы жизнеобеспечения. Выявлено, что продукция устойчивого развития туризма, в первую очередь оказанные туристические услуги, должна быть согласована с местной естественной средой, обществом и государством, их культурой и обычаями так, чтобы это приносило всем пользу, а не убыток туристической деятельности и тормозило дальнейшее развитие туризма.

Ключевые слова: принципы устойчивого развития; стратегическое управление; органы государственной власти; экологическая безопасность окружающей среды; природные ресурсы; экономическая деятельность; туристические объекты; курортно-рекреационные комплексы; культурное наследие. 


\section{NATURAL RESOURCE MANAGEMENT AND SUSTAINABLE DEVELOPMENT OF TOURISM IN THE CARPATHIAN REGION OF UKRAINE}

The main problems of natural resource management using and sustainable development of tourism in the Carpathian region of Ukraine are considered. This has made it possible to establish a balance between the satisfactions the current needs of the local population and protecting the interests of future generations, taking into account the safe state of the environment. The main priorities of the protection and ecologically safe uses of natural resources of the Ukrainian Carpathians in the economical and touristic activity of the region are allocated. The basic principles of the sustainable development of tourism in the region are formulated that will enable the state authorities to solve the economic problems of local communities and increase the tourist attractiveness of the region. The urgent problems of sustainable tourism development in the region of the Ukrainian Carpathians, the activity of which must be based on the principles of balanced development of the person, society and the state in conjunction with the environmental protection surrounding them, are analysed. It is established that sustainable tourism development in the Ukrainian Carpathians region should satisfy the current needs of tourists, holidaymakers and the local population as a whole. It is also necessary to use the available natural resources rationally and to increase the tourist potential of the region both now and in the future. It is revealed that local authorities should manage all tourist objects, resort and recreational complexes in order to satisfy the economic, social and aesthetical needs of tourists and local communities, and to preserve their cultural integrity, important ecological and economical processes, biological diversity and life support systems. It is revealed that the provided tourist services should be agreed first of all with the possibilities of the local natural environment, with the economic needs and opportunities of society and the state, their culture and customs. This should be done in such a way that tourist activity brings benefits to all, and not the damage to the tourism business.

Keywords: principles of sustainable development; strategic management; state authorities; ecological safety of the environment; natural resources; economic activities; tourist objects; resort and recreational complexes; cultural heritage. 